\title{
Effect Some Factors on the Structural Properties Of The CdS Thin Films Prepared By Chemical Bath Deposition
}

\author{
Fatma Salamon \\ Department of Physics, Faculty of Sciences, University of Al- Baath Homs, Syria. \\ Mobile: 00963-967941465 \\ E-mail: Benan8487@gmail.com
}

Keywords: Structure properties, CdS Thin films, Chemical Bath Deposition.

\begin{abstract}
CdS thin films were prepared by chemical bath deposition technique(CBD) onto the glass substrates at different conditions of preparation. The obtained samples are studied by X-Ray diffraction (XRD). The XRD patterns of CdS samples revealed the formation with a hexagonal crystal structure P36mc, and the clear effect of the concentration of thiourea, cadmium sulfide, $\mathrm{NaOH}$, time and temperature deposition, and annealing temperature ,on the structure of the prepared thin films. through the study, we found that the samples have preferred orientation along [002] , also the thickness of thin films decrease with deposition time after certain value, with the appearance of free cadmium. It has been found that the $200^{\circ} \mathrm{C}$ is the best temperature for annealing to improve the other structural and physical properties of films.
\end{abstract}

\section{1-INTRODUCTION}

The $I I-V I$ semiconducting compounds as ( $C d S e, C d T e, C d S$ ) have a great technological importance due to their application in the manufacture of optoelectronic devices [1]. $C d S$ is one of the important semiconductors has a relatively wide energy band gap $E_{g}=2.42 \mathrm{ev}$ and possesses ntype semiconductor characteristic, these properties make it a very desirable window layer for many heterojunction thin film solar cells [2]. $C d S$ can be prepared in a thin film form by a wide variety of deposition techniques [3].the preparation techniques includes vacuum evaporation[2][4], spray pyrolysis [5][6][7] ,screen printing [8], Solution Growth Process [9][10][11][12][13 ], this technique, also called as chemical bath deposition ( $C B D)[1]$, Some significant advantages for the $C B D$ method, compared with other physical and chemical deposition techniques, are the simplicity, inexpensiveness and the possibility to make the deposition under atmospheric conditions[14].

\section{2-EXPERIMENTAL DETAILS:}

$C d S$ thin films were deposited onto glass slide substrates which were cleaned by immersing them in the commercial cleaner Nocromix for $24 \mathrm{~h}$ and rinsing in distilled water and methanol .The chemical bath deposition of $C d S$ thin films were based on the reaction that happened at the substrate surface which included the following steps: At the first we given ions $\mathrm{Cd}^{+2}$ in water solution:

$$
\mathrm{Cd}\left(\mathrm{CH}_{3} \mathrm{COO}\right) \rightarrow \mathrm{Cd}^{+2}+2 \mathrm{CH}_{3} \mathrm{COO}^{-}
$$

in alkaline medium acts as an $S^{-2}$ ion source: thiourea

$$
\begin{gathered}
\mathrm{CS}\left(\mathrm{NH}_{2}\right)_{2}+\mathrm{OH} \rightarrow \mathrm{CH}_{2} \mathrm{~N}_{2}+\mathrm{SH}^{-}+\mathrm{H}_{2} \mathrm{O} \\
\mathrm{SH}^{-}+\mathrm{OH} \rightarrow \mathrm{S}^{-2}+\mathrm{H}_{2} \mathrm{O} \\
\mathrm{S}^{-2}+\mathrm{Cd}^{+2} \rightarrow \mathrm{CdS} \downarrow
\end{gathered}
$$

Fig(1)shows preparation thin films by chemical bath deposition (CBD) in the 


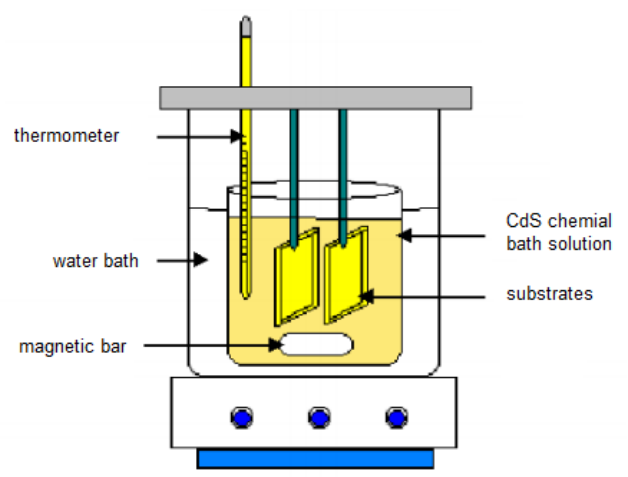

Fig (1) How preparation thin films by chemical bath deposition (CBD).

The color of reaction solution changed gradually to orange after a short time, this refers to starting the chemical reaction, we noted a thin orange layer of $C d S$ deposited on substrate surface with the time.

The substrates were hold from the chemical bath and washed with distilled water and dried.

\section{3-RESULTS AND DISCUSSION:}

\section{1-3 study the structure of $C d S$ powder:}

The powder was prepared by mixing two solutions: the first solution solve $10 \mathrm{gr}$ of cadmium acetate in $50 \mathrm{ml}$ distilled water and $10 \mathrm{gr}$ sodium sulfide in $50 \mathrm{ml}$ distilled water after that we were get a orange material of $C d S$ flowing the reaction:

$$
\mathrm{Cd}\left(\mathrm{CH}_{3} \mathrm{COO}\right)+\mathrm{Na}_{2} \mathrm{~S} \rightarrow \mathrm{Na}\left(\mathrm{CH}_{3} \mathrm{COO}\right)+2 \mathrm{CdS} \downarrow
$$

The material was washed many time for getting a crystal powder then dry then grind.

To make sure of this article is the study of X-ray diffraction spectrum which has been obtained by $\mathrm{x}$-ray diffraction device by comparing the spectrum with the spectrum cadmium sulfide in the data bank shows that the material we have obtained is amorphous cadmium sulfide according to the hexagonal structure and fixed network amounted to value $\left(a=3.5325 A^{\circ}, c=6.7128 A^{\circ}\right)$

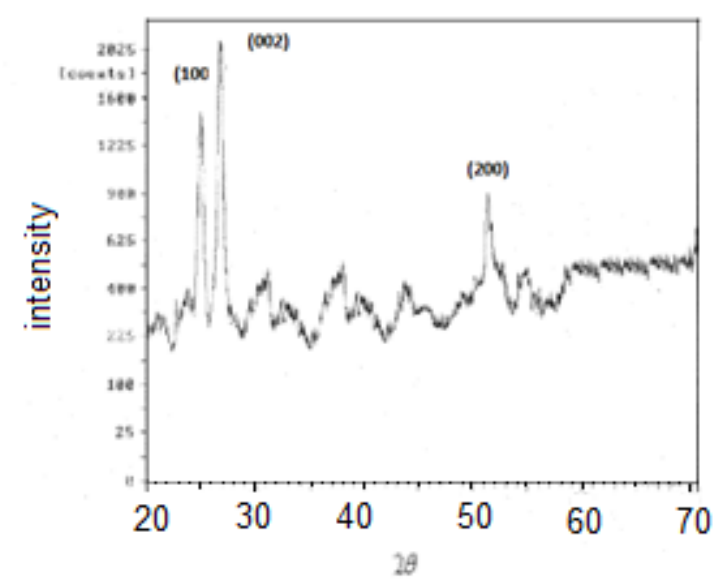

Fig (2) $X R D$ pattern of $C d S$ prepared powder.

\section{2-3 study the structure of $C d S$ thin films:}

$\mathrm{X}$-ray diffraction pattern of $C d S$ thin films Were studied and compares under different factors and conductions .

\section{1-2-3 the effect of thiourea $\left(\mathrm{CS}\left(\mathrm{NH}_{2}\right)_{2}\right)$ :}

The thiourea concentration plays an important role in the rate of development in the crystal structure of the resulting films where the main source of it (only) of sulfur in the reaction medium and the study of its effect is to prepare a new thin films of sulfide cadmium on glass substrates by 
taking different concentration for thiourea with the installation of the rest of the factors 2 of sodium hydroxide to make the center equal to 9 and was used $2 \mathrm{ml}$ of solution to reduce the amount of metal ions free in solution has been the use of $\mathrm{x}$-ray diffraction device for the spectra of these films, as shown in Fig(3)

Fig(3) shows XRD patterns of $C d S$ thin films were prepared at different low concentration of thiourea $(0.5-1-1.5-2 M)$. In comparing this patterns with the reference card of CdS in the data bank is to make sure that infrastructure is the approval of the structure of CdS.. showing clearly that the prepared thin have three main diffraction peak compatible crystalline levels $(100)(002)(200)$. It was cleared from comparison these patterns at different $(0.5-1-1.5-2 M)$ the best it was at $(1 M)$.

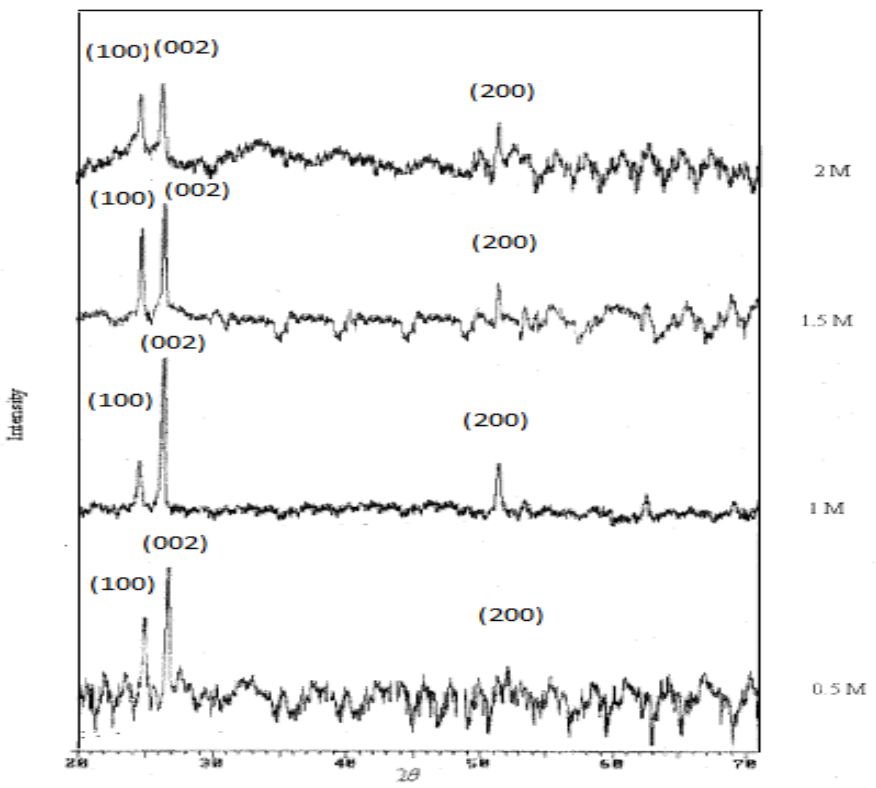

Fig (3) XRD patterns of $C d S$ thin films prepared at different concentration thiourea .

We noted at low concentrations of thiourea less than $(1 M)$ the thin films deposited growth was slow and resulted in low thickness and disruption in the XRD patterns, with increase the concentration of thiourea until $(1 M)$ the deposition rate became higher due to the increasing the ions ratio $S^{-2}$ and $C d^{+2}$ in the solution these help to increasing the growth rate on the substrate . but with increases concentration of thiourea $(1 M)$ the concentration the $S^{-2}$ ions in the solution become higher and the reaction goes to the opposite direction (to Le Chatelier law) due to the decreases the deposition rate. fig (4)shows increases thickness on the substrate with the concentration of thiourea.

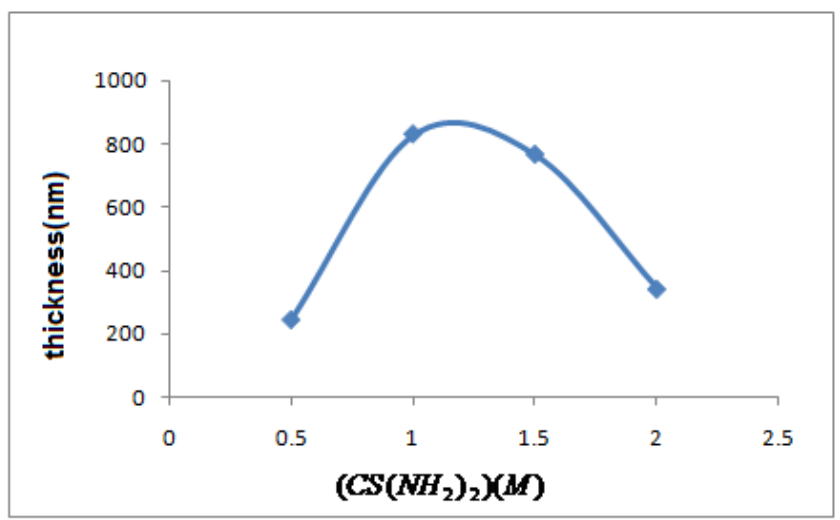

Fig (4) Changes the thickness of $C d S$ thin films at different concentration of $\left(\mathrm{CS}\left(\mathrm{NH}_{2}\right)_{2}\right)$ 
Table (1) show the values of thickness at different concentration of $\left(\mathrm{CS}\left(\mathrm{NH}_{2}\right)_{2}\right)$.

Table (1)

\begin{tabular}{|c|c|c|c|c||}
\hline$\left(\mathrm{CS}\left(\mathrm{NH}_{2}\right)_{2}\right)$ & 0.5 & 1 & 1.5 & 2 \\
\hline Thickness $(\mathrm{nm})$ & 244 & 829 & 765 & 340 \\
\hline
\end{tabular}

\section{2-2-3 the effect of cadmium acetate $\left(\mathrm{Cd}\left(\mathrm{CH}_{3} \mathrm{COO}\right)\right)$ :}

$\operatorname{Fig}(5)$ shows $X R D$ patterns of $C d S$ thin films were prepared at different concentration of cadmium acetate $(0.25-0.5-0.75 M)$ with fixing of the rest of the factors $(1 M)$ thiourea $(2 M) \mathrm{NaOH}$ for $(P H=10.5)$ and $(2 \mathrm{ml})$ TEA (trie tanola $\mathrm{min})$ and deposition time $(60 \mathrm{~min})$ and deposition temperature $\left(70 C^{\circ}\right)$.

Thin films have a crystalline structure characterizes by three main diffraction beak at $(2 \theta=24.95,26.54,51.51)$ agree crystalline levels $(100)(002)(200)$, the lattice constant was determined from this values and show it equal $\left(a=3.5825 A^{\circ}\right)$ it compatible well with the value of lattice constant for basic material for $C d S$.

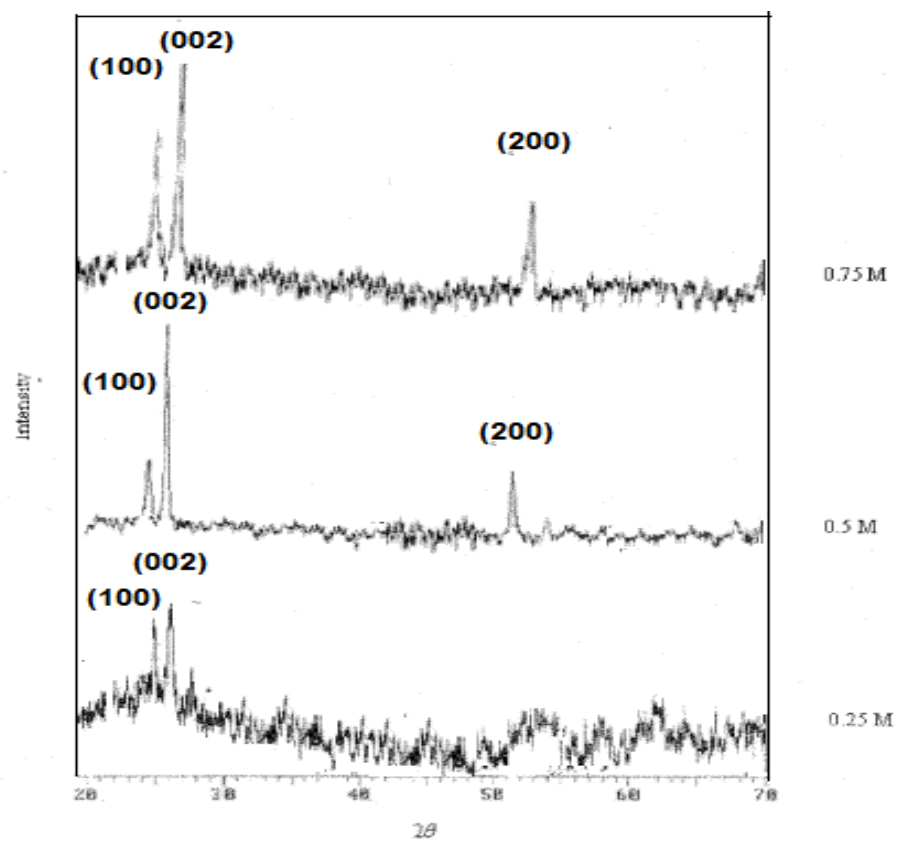

Fig (5) $X R D$ patterns of $C d S$ thin films prepared at different concentration cadmium acetate.

From comparison the thickness of these films fig (6) can you say the cadmium acetate concentration has important influence to form the prepared films through its impacting in the $\mathrm{Cd}^{+2}$ ions concentration in the reaction solution.

we note for the concentration cadmium acetate equal $(0.5 M)$ the growth of deposition films $C d S$ better and compatible a maximum thickness $(829 \mathrm{~nm})$.whereas increases the cadmium acetate concentration in the chemical solution more than $(0.5 M)$ increases $C d^{+2}$ ions ratio against $S^{-2}$ ions, these cause to make the reaction in opposite way and that could remove a part of thin layer formed at the substrate and cause decreasing the deposition average. 


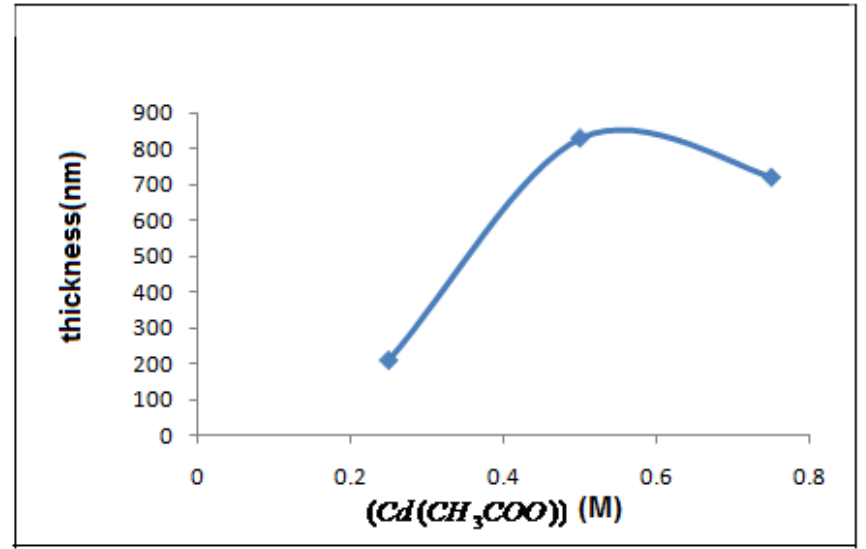

Fig (6) Changes the thickness of $C d S$ thin films at different concentration of cadmium acetate

Table (2) show the values of thickness at different concentration of cadmium acetate

Table $(2)$
\begin{tabular}{||c|c|c|c||}
\hline \hline$\left(\mathrm{Cd}\left(\mathrm{CH}_{3} \mathrm{COO}\right)\right)$ & 0.25 & 0.5 & 0.75 \\
\hline Thickness $(\mathrm{nm})$ & 210 & 829 & 720 \\
\hline
\end{tabular}

\section{3-2-3 the effect of $(\mathrm{NaOH})$ :}

For studying the effect( $\mathrm{NaOH})$ and therefore $\mathrm{PH}$ on the deposition was taken a different concentrations of $(\mathrm{NaOH})(1.5-2-2.5 \mathrm{M})$ with keep on the other variables $(0.5 \mathrm{M})$ $\left(\mathrm{Cd}\left(\mathrm{CH}_{3} \mathrm{COO}\right)\right)(1 \mathrm{M})$ thiourea $(2 \mathrm{ml})$ Trietanolamin for reduce the amount of free metal ions at constant deposition time and temperature. Fig (7) shows XRD patterns of $C d S$ thin films were prepared at different concentration of $(\mathrm{NaOH})$

fig $(8)$ show to the effect of $(\mathrm{NaOH})$ on the of thin films structure where note at concentration $2 \mathrm{M}$ $(\mathrm{NaOH})$ the diffraction spectra better than another spectra which refers to prepared films were crystalline very well.

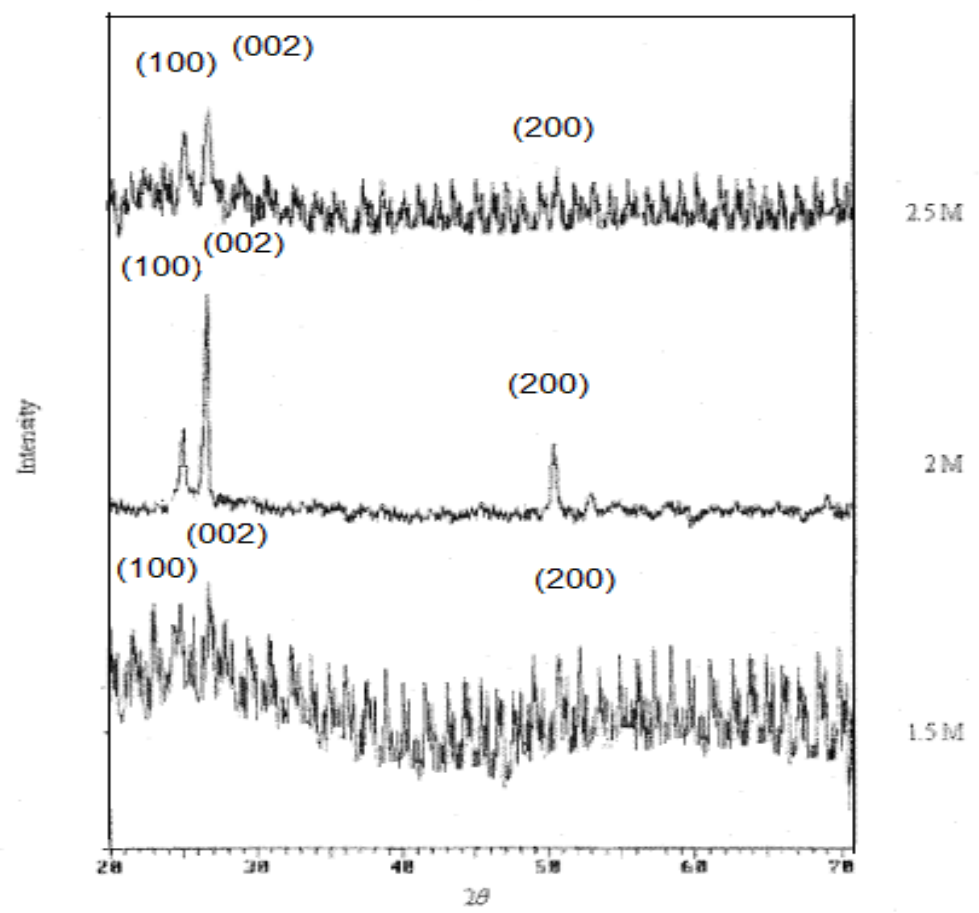

Fig (7) XRD patterns of $C d S$ thin films prepared at different concentration $(\mathrm{NaOH})$ 


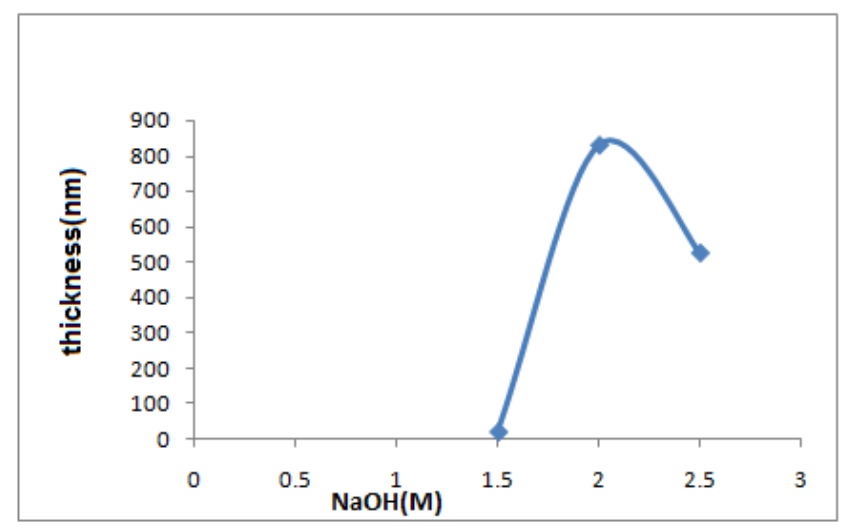

Fig (8) Changes the thickness of $\mathrm{CdS}$ thin films at different concentration of $(\mathrm{NaOH})$

Table (3) show the values of thickness at different concentration of $(\mathrm{NaOH})$.

Table $(3)$
\begin{tabular}{||c|c|c|c||}
\hline \hline$[\mathrm{NaOH}](\mathrm{M})$ & 1.5 & 2 & 2.5 \\
\hline Thickness $(\mathrm{nm})$ & 20 & 829 & 525 \\
\hline
\end{tabular}

\section{4-2-3 the effect of deposition temperature :}

$C d S$ thin films were prepared at different deposition temperature $\left(25-40-50-60-70-80 C^{\circ}\right)$, by used the following standard quantities $(0.5 M)$ cadmium acetate $(1 M)$ thiourea $(2 M) \mathrm{NaOH}$ for keep the $P H$ at constant deposition time at all cases. Fig(9) shows $X R D$ patterns of $C d S$ thin films were prepared at different deposition temperature.

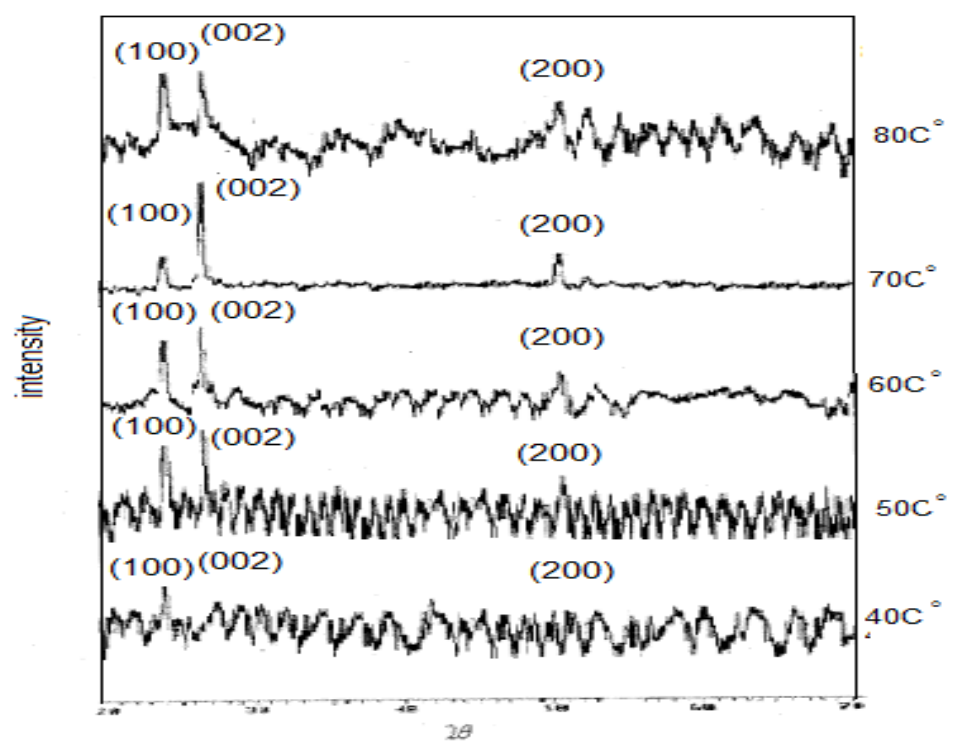

Fig (9) XRD patterns of $C d S$ thin films prepared at different temperature .

Fig (10) show at temperature higher and lower than $\left(70 C^{\circ}\right)$ the deposition growth average the thin films was slow and the thickness was low, the form of these lines refuse to deposition film was uncrystalline well. otherwise at temperature $\left(70 C^{\circ}\right)$ the $X R D$ patterns show there is sharp peak and the thin film has a good thickness . 


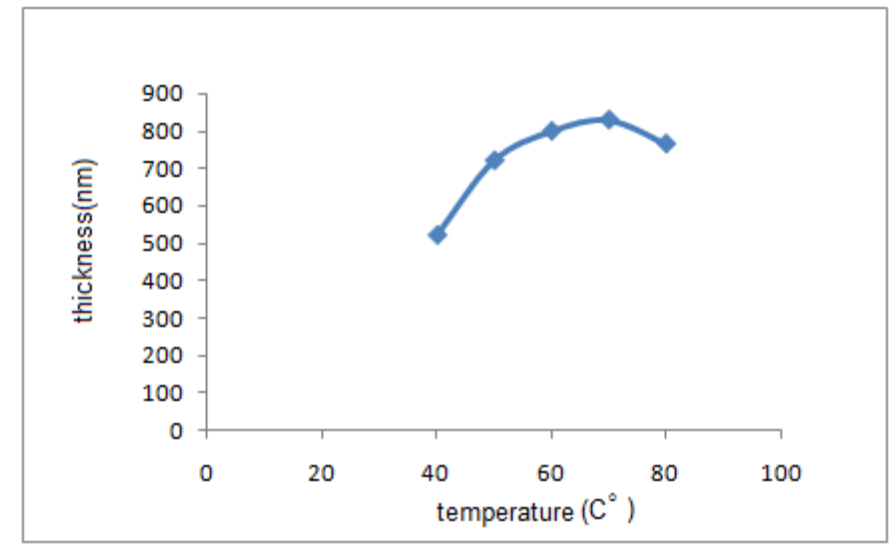

Fig (10) Changing the thickness of $C d S$ thin films at different temperature .

Table (4) shows values the thickness thin films at different temperature.

Table (4)

\begin{tabular}{||c|c|c|c|c|c||}
\hline Temperature $\left(\mathrm{C}^{\circ}\right)$ & 40 & 50 & 60 & 70 & 80 \\
\hline Thickness $(\mathrm{nm})$ & 520 & 720 & 799 & 829 & 765 \\
\hline
\end{tabular}

We can says: at temperature $\left(70 C^{\circ}\right)$ we get a thin film of $C d S$ which has better qualities than its counterpart in terms of gelling .

\section{5-2-3 the effect of deposition time :}

For study the effect of deposition time we had chose the best experiment conduction that had get before. $C d S$ thin films were prepared at different deposition time $(30-40-50-60-70 \mathrm{~min})$ at $\left(70 C^{\circ}\right) . \operatorname{Fig}(11)$ shows $X R D$ patterns of $C d S$ thin films were prepared at different deposition time $(30-40-50-60-70 \mathrm{~min})$.

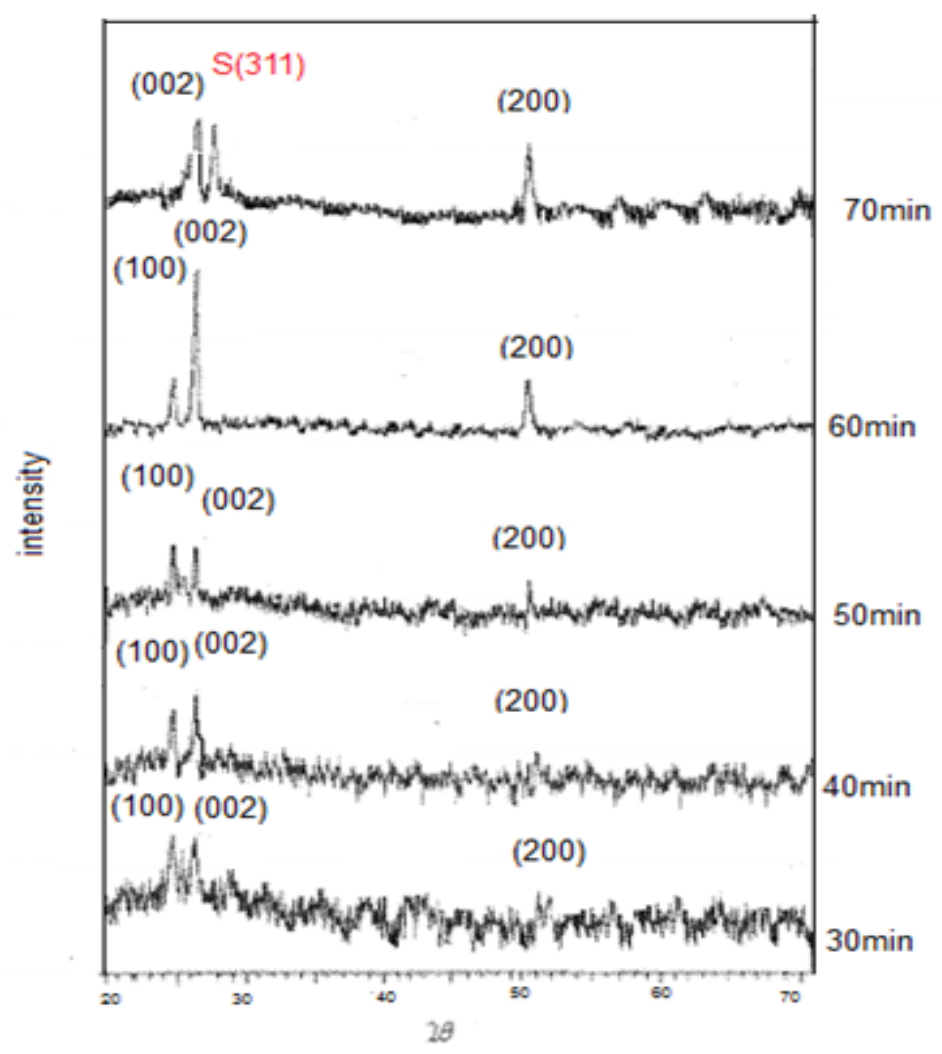

Fig (11) XRD patterns of $C d S$ thin films prepared at different deposition time 
by compression the results spectra with reference card of $C d S$ in the information bank JCPDS and in the fig (11) we found the most diffraction peaks compatible with the reference this confirms getting a thin films of $C d S$

the study spectra deceit to prepared thin films have a good crystalline structure at deposition time (60 min) characterizes by three main diffraction beak $(100)(002)(200)$ at $(2 \theta=24.94,26.549,51.51)$ and have preferred orientation along [002]. Table (5) shows the values preferred orientation at the deposition time (60min).

Table (5)

\begin{tabular}{||c|c|c|c||}
\hline$(h k l)$ & $(100)$ & $(002)$ & $(200)$ \\
\hline $2 \theta^{\circ}$ & 24.94 & 26.52 & 51.51 \\
\hline$I_{\text {thinf } i l m s}$ & 24.4 & 100 & 12.4 \\
\hline$I_{J C P D S}$ & 84 & 100 & 35 \\
\hline orientation & 0.55 & 1.90 & 0.69 \\
\hline
\end{tabular}

we note from the $X R D$ patterns of prepared thin films at $(70 \mathrm{~min})$ found a peak near (002). At studying and compression with the reference cards of sulfide and cadmium we found it back to the sulfide element that have a Orthorhombic structure S.G:Fddd(70)-(80-0247) as show in the following table :

Table (6)

\begin{tabular}{||c|c|c|c||}
\hline \hline$(h k l)$ & $(133)$ & $(026)$ & $(311)$ \\
\hline $2 \theta_{s}$ & 24.920 & 25.878 & 26.345 \\
\hline $2 \theta_{f i m}$ & 24.325 & 25.545 & 26.645 \\
\hline
\end{tabular}

The thickness of prepared thin films was measured by weight method Fig (12) shows changing the thickness thin films as deposition time

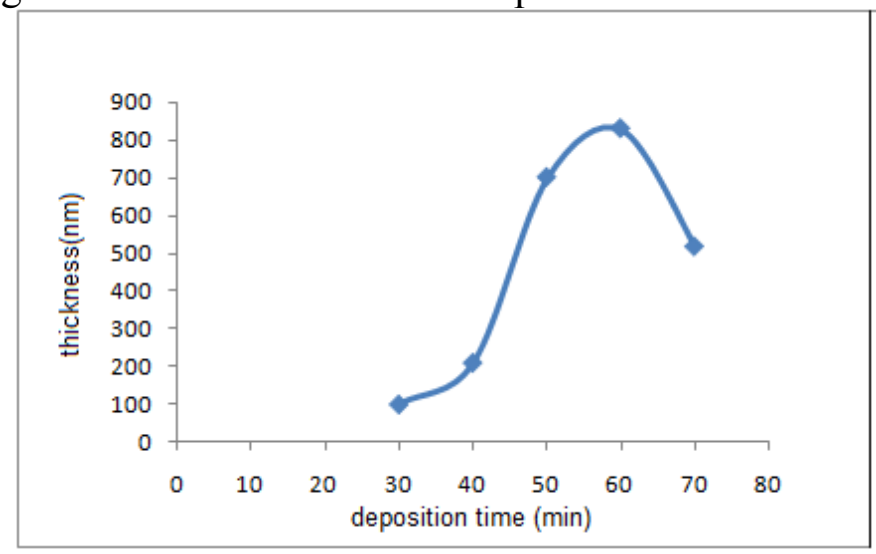

Fig (12) Changes the thickness of $C d S$ thin films at different deposition time.

Table (7) shows values the thickness thin films at different deposition time .

Table (7)
\begin{tabular}{|c|c|c|c|c|c||}
\hline Time(min) & 30 & 40 & 50 & 60 & 70 \\
\hline Thickness $($ nm) & 99 & 209 & 700 & 829 & 517 \\
\hline
\end{tabular}

The thickness of thin film increases with increasing the deposition time until $(60 \mathrm{~min})$ Where the crystalline is the best, after that time the thickness of thin films decreases with increases the deposition time. beside that we note apparent a spectra peaks to the sulfide element that refuse to dissolution a part of $C d S$ and deposited the sulfide these causes decreases the thickness of thin film $C d S$ 
These due to the :

In the first a white deposition formed after adding $\mathrm{NaOH}$ to the cadmium acetate , these deposition causes unexpected decreasing in the cadmium ions and it is possible to express the following equations :

$$
\begin{aligned}
& \mathrm{Cd}\left(\mathrm{CH}_{3} \mathrm{COO}\right)_{2}+2 \mathrm{NaOH} \rightarrow \mathrm{Cd}(\mathrm{OH})_{2}+2 \mathrm{Na}\left(\mathrm{CH}_{3} \mathrm{COO}\right) \\
& \mathrm{Cd}(\mathrm{OH})_{2}+4 \mathrm{NaOH} \rightarrow \mathrm{Na}_{2} \mathrm{Cd}(\mathrm{OH})_{6} \\
& \mathrm{Na}_{2} \mathrm{Cd}(\mathrm{OH})_{6} \rightarrow 4 \mathrm{Na}^{+}+\mathrm{HCdO}_{3}+3 \mathrm{OH}+\mathrm{H}_{2} \mathrm{O} \\
& \mathrm{H}_{2} \mathrm{~N}-\stackrel{\mathrm{S}}{\mathrm{C}}=\mathrm{NH}_{2} \leftrightarrows \mathrm{H}_{2} \mathrm{~N}-\stackrel{\mathrm{SH}}{\mathrm{C}}=\mathrm{NH}
\end{aligned}
$$

The exist $\mathrm{Cd}(\mathrm{OH})_{2}$ in reaction solution is very important for deposited $\mathrm{CdS}$ where it is essential factor in perpetration complex $\mathrm{NaCd}(\mathrm{OH})_{6}$ in reaction which after that dissolve to give $\left(\mathrm{HCdO}_{3}\right)$ which reacted with thiourea in alkali, this means the concentration thiourea an $\mathrm{d} \mathrm{NaOH}$ have a important in causes reaction subsequently deposition the thin films as following:

thiouera dissolve in alkali and give sulfide ions in the reaction solution:

$$
\begin{aligned}
& \mathrm{H}_{2} \mathrm{~N}-\stackrel{\mathrm{SH}}{\|} \underset{\mathrm{C}}{\|}=\mathrm{NH} \leftrightarrows \mathrm{H}_{2} \mathrm{~N}-\stackrel{\mathrm{OH}}{\mathrm{C}}=\mathrm{NH}+\mathrm{SH}^{-} \\
& \mathrm{HCdO}_{2}^{-}+\mathrm{SH}^{-} \rightarrow \mathrm{CdS}+2 \mathrm{OH}
\end{aligned}
$$

After $60 \mathrm{~min}$ of starting reaction the thiourea decomposition increases these cause the considerable increasing sulfide ions against cadmium ions in reaction solution, in other hand the excrescence ions do according to Le Chatelier law to reverse reaction direction which cause attract cadmium ions from the deposition layer toward the solution, so cadmium ions leave the deposition layer leaving behind it sulfide ions within the crystalline structure of cadmium sulfide for that the diffraction peaks belonging to the spectral peaks of sulfur.

\section{6-2-3 the effect of annealing :}

$\mathrm{CdS}$ result thin films annealed at different temperature $\left(150,200,250 C^{\circ}\right)$ fig (13) shows $X R D$ patterns of $C d S$ thin films prepared at different annealing temperature.

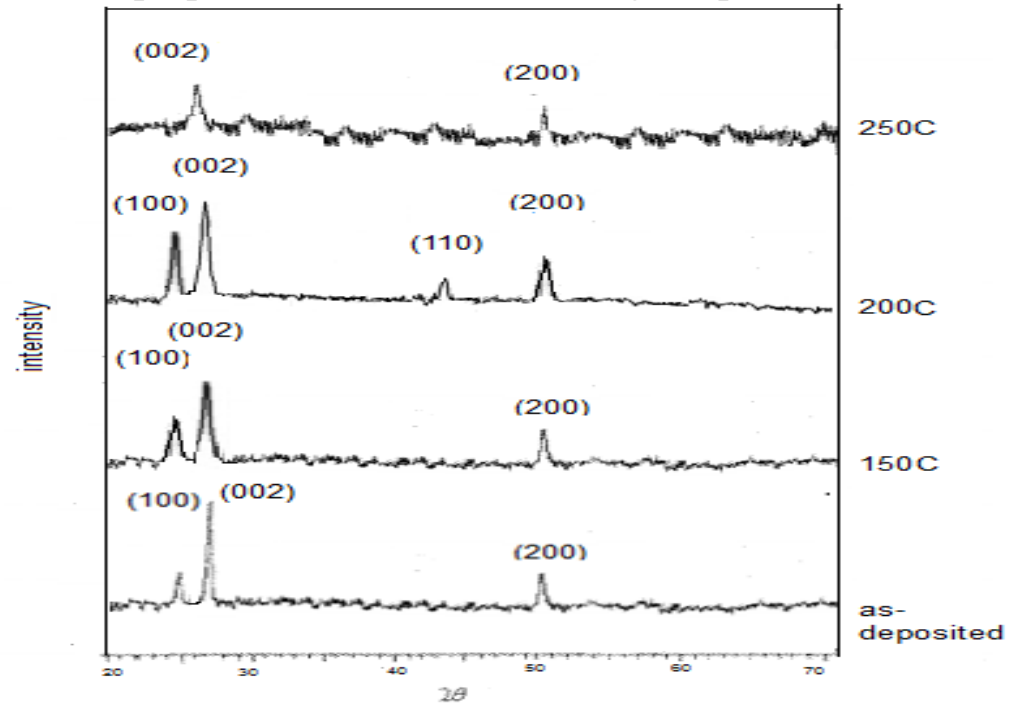

Fig (13) XRD patterns of $C d S$ thin films prepared at different annealing temperature .

Fig(13) show when raise the annealing temperature increase in the intensity and severity of diffraction peaks occur which shows the improvement in the Crystallization preparation thin films. when we annealed thin films at different temperature that we came to at temperature $200^{\circ} \mathrm{C}$ the crystalline is the beast and when increasing annealing temperature above $200^{\circ} \mathrm{C}$ we note the beginning the incoherence complex and destruction of the crystalline structure. 


\section{4-CONCLUSIONS:}

In this work we got thin films of CdS on glass slide substrates by chemical bath deposition technique at deposition time (60min) and deposition temperature (70c) where the material rates $(1 \mathrm{M})$ thiouera and $(0.5 \mathrm{M})$ cadmium sulfide and $(1 \mathrm{M}) \mathrm{NaOH}$ and $(2 \mathrm{ml})$ of TEA. It has been found that the $200^{\circ} \mathrm{C}$ is the best temperature for annealing to improve the other structural and physical properties of films.

\section{References}

[1] ABULLH SERHAN AL-SHAMMARI-(2005)- Preparation and characterization of chlorine doped cadmium sulphide (CdS:Cl) thin films and their application in solar cells .King saud university, Colleg of Science, Departement of physics and Astronomy.

[2] H.CHAVEZ, *M.JORDAN, J.C.McCLURE, *G.LUSH, V.P.SINGH-(1997)-Physical and electrical characterization of CdS films deposited by vacuum evaporation, solution growth and spray pyrolysis.

[3] M.H.BADAWI.S.ABOUL-ENEIN.M.GHALI. and G.HASSAN -(1998)- Physical properties of chemically deposition CdS for solar cells. department of physics, faculty of science , tanta univ. tanta, Egypt -PII: S0960-1481-(98)00055-X.

[4] D Kathirvel, N Suryanarayanan, R Jeyachitra, (2014), structure, surface morphology and elemental composition analysis on $\mathrm{CdS}$ thin films prepared by vacuum evaporation deposition, vol.6, NO7, pp3456-3466.

[5] SUNNY MATHEWS, P. S. MUKERJEEB, K. P. VIJAYAKUMAR-(1995)- Optical and surface properties of spray-pyrolysed CdS thin films. Thin Solid Films 254 (1995) 278-284.

[6] P RAJI, C SANJEEVIRAJA $\dagger$ and K RAMACHANDRAN.-(2005)-Thermal and structural properties of spray pyrolysed CdS thin film.indian Academy of Sciences,233-238p.

[7] KODIGALA SUBBA RAMAIAH-(1999)- Electrical properties of In doped CdS thin flms). MATERIALS IN ELECTRONICS 10 (1999) 291-294.

[8] V.Kumar,D.K.Sharma, M.K.Bansal,D.K.Dwivedi, (2001), synthesis and characterization of screen-printed CdS films, science of sintering. 43(20011)335.341.

[9] S. Soundeswaran, O. Senthil Kumar, R. Dhanasekaran- Effect of ammonium sulphate on chemical bath deposition of CdS thin films.. Materials Letters 58 (2004) 2381- 2385.

[10] JOEl PANTOJA ENRLIQUEZ, XAVIER MATHE-(2003) Influence of the thickness on structural, optical and electrical properties of chemical bath deposited CdS thin films. Solar Energy Materials \& Solar Cells 76 (2003) 313-322.

[11] G. Mustafa1, M. R. I. Chowdhury2, D. K. Saha3, S. Hussain2, and O. Islam2. Dhaka Univ. J. Sci Annealing Effects on the Properties of Chemically Deposited CdS Thin Films at Ambient condition. -60(2): 283-288, 2012 (July).

[12] Awodugba A.O, Adedokun.O and Sanusi Y.KIOSR Journal of Applied Physics (IOSR-JAP) eISSN-(2014)- Annealing Effect of Temperature on the Optical Properties of Nanostructure CdS Films.2278-4861.Volume 6, Issue 2 Ver. I (Mar-Apr. 2014), PP 34-39 www.iosrjournals.

[13] S. Prabahar, M. Dhanam. - (2005)- CdS thin films from two different chemical bathsstructural and optical analysis. Journal of Crystal Growth 285 (2005) 41-48.

[14] Andreas Fredriksson - (2006) - Kinetics of collector In-Situ Adsorption on Metal Sulphide Surfaces Studied by ATR-FTR Spectroscopy, 2006:52. 